\title{
Isolation and Molecular Identification of Endophytic Mold Schizophillum commune in Red Dahlia (Dahlia sp. L) Tuber as Producing Inulinases
}

\author{
Sunarti Sunarti ${ }^{1 *}(\mathbb{D})$, Chrismis Novalinda Ginting ${ }^{2}$, Sahna Ferdinand Ginting ${ }^{3}$ \\ ${ }^{1}$ Department of Medical Science, Doctoral Program of Medicine, Prima Indonesia University, Medan, Indonesia; ${ }^{2}$ Department \\ of Biomolecular, Faculty of Medicine, Prima Indonesia University, Medan, Indonesia; ${ }^{3}$ Department of Clinical Pathology, Faculty \\ of Medicine, Prima Indonesia University, Medan, Indonesia
}

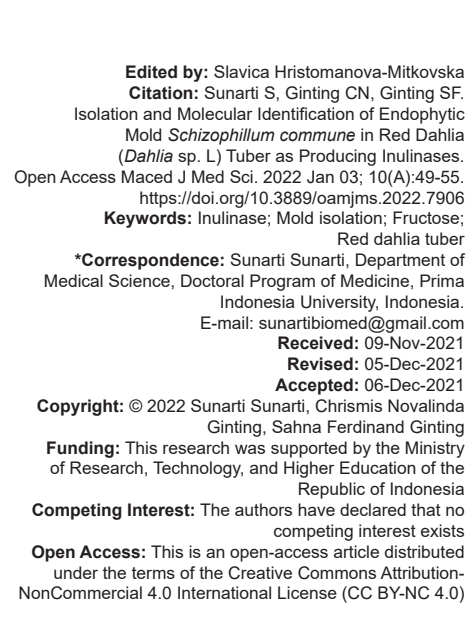

Introduction

Dahlia is a flower that has bulbs from the Asteraceae family. Dahlia is a raw material that is high in inulin, which is about $15-20 \%$. Inulin is a natural dietary fiber and low glycemic index that have a fructosyl compound at the terminal. Inulin is a substrate and inducer for the production of inulinase. From this enzymatic process, the biotechnological potential of high inulin feedstock is explored for the production of various important industrial products. Raw materials high in inulin can be used for the production of fructooligosaccharides (FOS) and fructose. Fructose is a low-calorie sugar that can be used by people with diabetes mellitus [1].

The development of modern biotechnology currently has the opportunity for the enzyme industry to treat all types of agricultural waste that will be used as high-value products, for example, the availability of cheap and abundant inulin from dahlia tubers as agricultural waste can be processed through hydrolysis of inulin by targets on the $\beta-2,1$ linkage of inulin into fructose with D-fructose content is more than 95\% [2]. Hydrolysis of inulin by one step using inulinase gives a yield of approximately 90-95\% fructose better than conventional fructose production from starch requires at least three enzymatic steps involving amylase, glucoamylase, and glucose isomerase and yields only $45 \%$ fructose [3].

Inulin besides being able to be processed as an ingredient in high-fructose and FOS syrups; it can also be used for various products such as sorbitol, citric acid, single-cell oil, single cell protein, bioethanol, lactic acid, glutamic acid, and various other products [4].

Fructose and FOS are the main products of inulin. Inulin is a natural fiber that is low in calories, safe to use for diabetics, besides that it can improve the growth of intestinal flora, increase iron absorption in children, overcome digestive problems such as irritable bowel syndrome, obesity, lower cholesterol, and overcome other health problems [5].

Inulin content in addition to being found in dahlia tubers is also found in chicory, Jerusalem artichoke, 
potato tuber Yaco'n, Asparagus, onion, garlic, wheat, and banana which can be processed pharmacologically as a prebiotic to improve the intestinal microbial environment, regulate blood sugar, regulate blood lipids, antioxidants, anticancer, immune regulation, and so on. Meanwhile, in the food industry, inulin can be used as thickeners, fat substitutes, sweeteners, and water-retaining agents [6].

The management of inulin can be done enzymatically by microbial inulinase. A number of microbial groups such as bacteria, fungi, and yeasts has been exploited for inulinase. It is of the several species that have the best growth against environmental and high osmotic conditions as producers of inulinase are fungi [7].

Inulinase is an enzyme produced by plants, animals, and microbial sources that are induced by inulin. Inulin is a substrate and an effective carbon source as a producer of inulinase. Potential sources of inulinase-producing microbes are bacteria, fungi, and yeasts. However, fungi can be the main choice because they can grow on better substrates and require lower costs. So that this enzymatic reaction is very beneficial because it produces various important industrial products from these inulinolytic enzymes such as fructose and FOS [8].

Inulinase was developed today because of its cheap and abundant supply. These inulinase-producing microorganisms can be cultured in an inulin-rich medium, wherein inulin from dahlia tubers can be used as an inducer and a carbon source for inulinaseproducing. Fungal growth as an inulinase producer needs attention, especially in temperature and $\mathrm{pH}$ regulation. Temperature and $\mathrm{pH}$ play an important role in the best inulinase production, which is in the range of $\mathrm{PH} 4-6.5$ [9].

The results of the previous studies found that plant materials containing inulin such as dahlia, garlic, and Jerusalem artichoke could be used as a carbon source to produce the best inulinase compared to the purified substrate. Inulinases produced from these plant materials have higher profits and lower production costs when compared to purified substrates [10].

Another study also found that chicory root as a substrate produced the highest inulinase in Aspergillus niger among of 12 the tested strains with a clear zone diameter on agar plates after hydrolysis of inulin used iodine solution was $40 \mathrm{~mm}$ and the value of inulinase activity was $102.3 \mathrm{U} / \mathrm{mL}$ [11].

An important phase should be done to obtain a big-scale inulinase enzyme through mold isolation. To isolate inulinase in a great amount from plants is somewhat difficult, so this research is important to do to find out the type of endophytic mold which had the highest inulinase activity through isolation and identification of endophytic mold molecular in red dahlia tuber. It was also aimed to get a new isolate of endophytic mold which had the highest inulin activity so that it could get a new variant of the inulinase enzyme which could be used in industry to produce fructose enzymatically.

\section{Materials and Methods}

This type of study is a descriptive study. Identification was carried out by morphological, microscopic, and molecular observations to determine the type of inulinase-producing endophytic mold in red dahlia. This study was performed in Mei 2021 at the Biology Molecular Laboratory of the Faculty of Medicine, Prima Indonesia University. This study has been approved by Health Research Ethics Committee from Prima Indonesia University.

\section{Isolation of inulinase producing endophytic mold}

Endophytic mold isolation producing inulinase obtained from red dahlia tuber from Berastagi, North Sumatera in Indonesia. The initial step is to sterilize dahlia tubers in stages, which is done twice in a row using $96 \%$ ethanol for $30 \mathrm{~s}, 1 \% \mathrm{NaOCl}$ for $1 \mathrm{~min}$, and $70 \%$ ethanol for $30 \mathrm{~s}$. Dahlia tubers were then cut into small pieces, placed on a petri dish containing potato dextrose agar (PDA), and incubated at room temperature. The mycelium that grew from the dahlia tubers was then transferred to agar in a new PDA dish with a mixture of $1 \%$ inulin and $250 \mathrm{~g}$ clorampenicol as an anti-bacterial, where each isolates with codes UD1, UD2, UD3, UD4, and UD5, and they were incubated at the room temperature of $30^{\circ} \mathrm{C}$ in $72 \mathrm{~h}$ or until pure cultures are obtained. Each pure culture of the fungus was observed for color and colony morphology macroscopically and microscopically.

\section{Inulinase activity screening}

Screening inulinase activity in the isolates was screened using PDA medium and $1 \%$ of inulin powder, after isolates were incubated at $28-30^{\circ} \mathrm{C}$ for $5-7$ days; a qualitative inulinase test was carried out by adding Lugol's solution to see the hydrolysis of inulinase, Lugol iodine was poured into the petri dish for 3-5 min and removed after that aquabidest was poured to remove the remaining Lugol's iodine. The clear zone indicated inulin hydrolysis by the mold. Positive results are indicated by the presence of a clear zone around the endophytic mold, while negative results are indicated by the absence of a clear zone [12].

Inulinase activity grouped into three categories: Low activity with the ratio of the area of clear zone toward the colony area of $<1$, was given a symbol $(+)$, 
moderate activity $<1-2(++)$, high activity with the ratio $>2(+++)$. The isolates with the highest inulinase activity were further identified molecularly [13].

\section{Isolation inulinase enzyme (Crude enzyme)}

Fermentation culture was prepared by taking a number of mold isolates dissolved in $25 \mathrm{ml}$ of potato dextrose broth (PDB) medium at $\mathrm{pH}$ 5.0. It was incubated in a shaking incubator at the velocity of $160 \mathrm{rpm}$ for $72 \mathrm{~h}$ at the temperature of $30^{\circ} \mathrm{C}$. To extract inulinase crude enzyme of $2.5 \mathrm{~mL}$, fermentation culture was put into Erlenmeyer flask containing $25 \mathrm{~mL}$, inulinase enzyme isolation medium consisted of $1 \%$ of inulin, $\left(\mathrm{NH}_{4}\right)_{2} \mathrm{PO}_{4} 0.5 \%, \mathrm{MgSO}_{4}, 7 \mathrm{H}_{2} \mathrm{O} 0.05 \%$, and $\mathrm{FeSO}_{4} 0.015 \% \mathrm{pH} 5.0$. It was then incubated for $120 \mathrm{~h}$ in a shaking incubator at the velocity of $160 \mathrm{rpm}$ at the temperature of $30^{\circ} \mathrm{C}$. From this incubation, a suspension of inulinase enzyme will be produced which is then centrifuged at $3.500 \mathrm{rpm}$ for $15 \mathrm{~min}$. The filtrate was a crude inulinase enzyme [14].

\section{Determination of the standard curve}

The making of fructose calibration curve is a standard fructose concentration that was prepared in some reaction tubes with the graded concentration of 20-90 mL of the fructose main solution of $1.000 \mathrm{mg} / \mathrm{L}$ plus $1 \mathrm{~mL}$ of reagent Nelson. Reaction tubes were heated in the water heater for $30 \mathrm{~min}$. Reaction tubes were cooled in running water until the temperature was $25^{\circ} \mathrm{C}$, added with $1 \mathrm{~mL}$ of Arsenomolibdat solution, stirring until all the precipitate was dissolved, $7 \mathrm{~mL}$ of aquadest was added and mixed again until it was homogeneous. Absorbance was measured with an ultraviolet-visible (UV-Vis) spectrophotometer at a wavelength of $499 \mathrm{~nm}$ [15].

\section{Inulinase enzyme activity test}

Testing for inulinase activity was carried out by preparing a test tube containing $0.1 \%$ inulin solution, $0.5 \mathrm{ml}$ of the crude enzyme, $1 \mathrm{~mL}$ of $0.1 \mathrm{M}$ acetate buffer at $\mathrm{pH} 5.0$, and then incubated at $35^{\circ} \mathrm{C}$ for $15 \mathrm{~min}$. After that, $1 \mathrm{~mL}$ of Nelson's reagent was added and reheated for $30 \mathrm{~min}$, after being cooled, $1 \mathrm{~mL}$ of Arsenomolybdate solution, and $7 \mathrm{~mL}$ of distilled water were added and stirred until homogeneous. The determination absorbance was measured using a UV-Vis spectrophotometer at a wavelength of $499 \mathrm{~nm}$ [16].

\section{DNA isolation}

DNA isolation was done in each mold isolate obtained from the result of purification. DNA isolation, that is, mycelium was inoculated in $10 \mathrm{~mL}$ of PDB medium in the vial tube, and then grow it rotary shaker in $72 \mathrm{~h}$. Then, the harvesting of mycelia was done by centrifugation method with a velocity of $13.000 \mathrm{rpm}$ in $15 \mathrm{~min}$. The supernatant was removed, and only its pellets were taken out. The pellets were washed with $500 \mu \mathrm{L}$ TE buffer (with $\mathrm{pH}$ 8) and $300 \mu \mathrm{L}$ extracted buffer. $150 \mu \mathrm{L}$ of sodium acetate $\mathrm{pH} 5.2$ was added after it was incubated at the temperature of $20^{\circ} \mathrm{C}$ within $10 \mathrm{~min}$. After that, it was centrifugated with a velocity of $13.000 \mathrm{rpm}$ in $5 \mathrm{~min}$, and its supernatant of $600 \mu \mathrm{L}$ was taken out and moved into a new microtube. Isopropanol was added to the microtube containing supernatant with the same volume and centrifugated with a velocity of $13.000 \mathrm{rpm}$ in $10 \mathrm{~min}$. After that, DNA was washed with $500 \mu \mathrm{L}$ of $\mathrm{ETOH}(70 \%$ ethanol) and dried up and dissolved with $20 \mu \mathrm{L}$ of buffer TE, and kept in a freezer at the temperature of $-20^{\circ} \mathrm{C}$ [17].

\section{Polymerase chain reaction (PCR) amplification and elektroforesis}

DNA as a result of extraction was amplified using Esco Swift MaxPro thermal cycler. Gen internal transcribed spacers (ITSs) were amplified using ITS 1 Primer and ITS 4. Total volume PCR was made $50 \mu \mathrm{L}$ consisted of containing $2 \mu \mathrm{L}$ of DNA isolate, $10 \mu \mathrm{L}$ of each primer concentrating 2 olmol, $5 \mu \mathrm{L}$ dNTP concentrating 2 $\mathrm{mM}, 10 \mu \mathrm{L}$ buffer $+5 \mu \mathrm{L} \mathrm{MgCl}, 7.75 \mu \mathrm{L} \mathrm{H}_{2} \mathrm{O}$, and $0.25 \mu \mathrm{L}$ Go Taq DNA polymerase. The reaction begins with a hot star at $95^{\circ} \mathrm{C}$ for $5 \mathrm{~min}$, denaturation at $94^{\circ} \mathrm{C}$ for $1.5 \mathrm{~min}$, annealing process at a temperature of $53^{\circ} \mathrm{C}$ for $1 \mathrm{~min}$, and an extension process at $72^{\circ} \mathrm{C}$ for $3 \mathrm{~min}$. This PCR reaction process lasts for 35 cycles. The primer used was universal ITS $1 /$ ITS 4 primer, ITS 1 as a reverse primer, and ITS 4 as forwarding primer. Primer ITS 1 is $5^{\prime}$ (TCC GTA GGT GAA CCT GCG G) 3' and primer ITS 4 is 5' (TCC TCC GCT TAT TGA TAT GC) 3' [18].

Analysis of the amplified DNA was carried out by electrophoresis using $0.8 \%$ agarose gel for DNA extraction, while PCR amplification used 1.2\% agarose gel. Electrophoresis was carried out by taking $3 \mu \mathrm{L}$ of $100 \mathrm{bp}$ marker and loading dye $1 \mu \mathrm{L}$ then resuspended and put into wells in $1.2 \%$ agarose gel. The PCR product from the sample was then taken as much as $3 \mu \mathrm{L}$, and put into a well in $1.2 \%$ agarose gel, then electrophoresed for 30 min with a voltage of 110 volts. Then, the gel was soaked with ethidium bromide after the electrophoresis was completed and analyzed with a UV transilluminator [19].

\section{DNA sequencing}

The amplified DNA was used for DNA sequencing steps based on the dideoxy nucleotide chain termination method (Macrogen Inc., South Korea). The results of DNA sequencing were then compiled using the Bioedit program and analyzed using the BLAST program using information from Genbank (http://www. ncbi.nlm.nih.gov) [20]. 

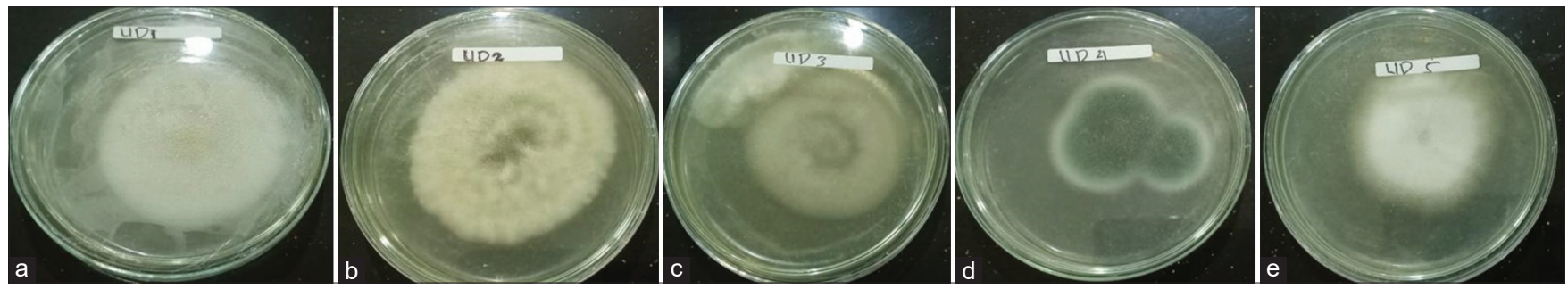

Figure 1: Macroscopic mold morphology from endophytic mold isolation of red dahlia root: (a) UD1, (b) UD 2, (c) UD 3, (d) UD 4, and (e) UD 5

\section{Result}

The result of mold isolation of red dahlia tuber showed that five types of mold which were given their labels as UD1, UD2, UD3, UD4, and UD 5 are shown in Figure 1. After the result had been obtained, each of the mold types was treated with pure breeding as stock culture. From the mold isolate, observation was done macroscopically and microscopically. Coloring with lactophenol cotton blue was done in microscopic observation Figure 2. The result of macroscopic and microscopic observation is shown in Table 1.

The result of screening of inulinase activity was done three repetitions with pure media dripped with Lugol iodine and cleaned up its remaining Lugol with aquadest so that inulinase activity measurement was obtained by measuring clear zone in the mold as it is shown in Table 2 below. It was followed by measuring inulinase activity in the mold isolate which had the highest inulinase: UD 3, UD 4, and UD 5 as they are shown in Table 3.

After the inulinase activity test had been done, it was followed by identifying the molecular with ITS primer. Primer used to amplify rDNA and the result of DNA sequencing with ITS 1 and ITS 4 is shown in Table 4 and Figure 3.

The result of identifying molecular is shown in Tables 5 and 6.

The result of measuring the highest inulinase in UD 5 was 0.685185185 and molecular identification was done with ITS 1 primer and ITS 4 primer which showed that UD 5 which had the highest inulinase activity was mold with species $S$. commune from the Schizophillaceae family.

\section{Discussion}

The endophytic mold isolated from red dahlia tubers had five isolates, each of which was labeled UD1, UD 2, UD3, UD4, and UD 5. Each isolate had almost the same color, namely, white, and among the isolates, the isolates were white, which has the highest activity is UD 5, namely: 0.685185185 , and from the results of molecular identification with the ITS1 and ITS4 regions, it was successful to identify the endophytic mold species S. commune (Figure 5).

This study explores the types of inulinaseproducing endophytic molds that will be used by the industrial world to produce fructose and FOS through an enzymatic process so that inulinase is an important isolate in industry and pharmaceuticals as a basic ingredient for various foods and medicines.

Inulinase is a very important hydrolytic enzyme whose contents are composed of fructose monomer units with $\beta-D-2,1$ glycosidic linkages and have glucose moiety at the reducing end joined by an $\alpha$-D-1,2 glycosidic linkage. Inulinase can be categorized into two types, namely, endoinulinase and exoinulinase. Exoinulinase cleaves $\beta-2,1$ bonds sequentially to produce fructose, while endoinulinase cleaves randomly and hydrolyzes internal bonds in inulin to produce FOS [21].

Fructose can be classified as a natural sweetener with low calories; it has a level of sweetness of $70 \%$ which is higher than sucrose so that it is safe to be consumed by diabetes patients. Fructose can also be used as an alternative sweetener as the substitute for artificial sweetener. Another important application of the inulinase enzyme, among others, is for prebiotic production such as inulooligosaccharides andFOS. It

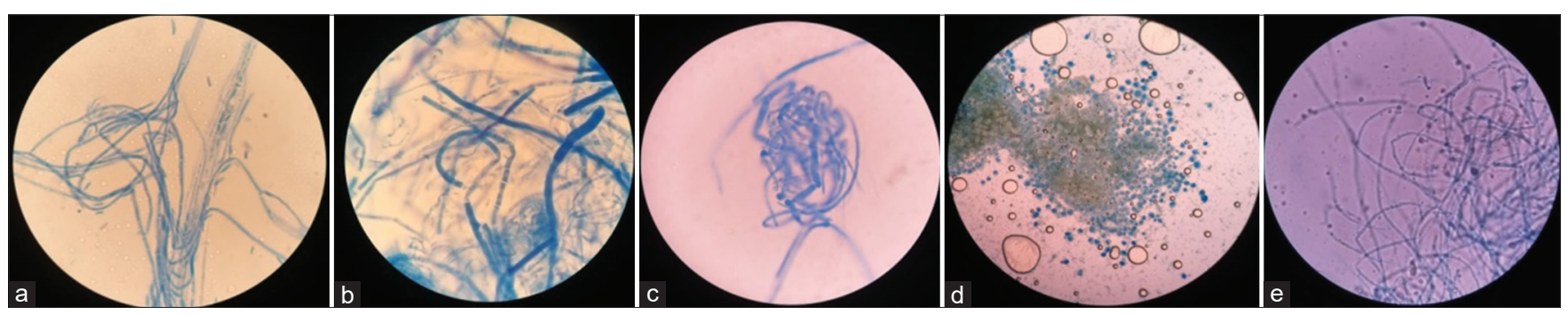

Figure 2: Microscopic mold morphology from endophytic mold isolation of red dahlia root: (a) UD1, (b) UD 2, (c) UD 3, (d) UD 4, and (e) UD 
Table 1: Result of observation of macroscopic and microscopic endophytic mold morphology

\begin{tabular}{|c|c|c|c|}
\hline No & $\begin{array}{l}\text { Types of } \\
\text { Mold }\end{array}$ & Macroscopic Observation & Microscopic Observation \\
\hline 1. & UDI & $\begin{array}{l}\text { Upper part: Milky white hyphae, white } \\
\text { meselenium, yellowish spore, and } \\
\text { thick colony } \\
\text { Reverse: Yellowish hyphae, brownish } \\
\text { spore, thick colony, and in order }\end{array}$ & $\begin{array}{l}\text { Septate hyphae, non-branchy } \\
\text { miselineum, transparent hyphae } \\
\text { stem, and spore }(+)\end{array}$ \\
\hline 2. & UD 2 & $\begin{array}{l}\text { Upper part: White hyphae, greenish } \\
\text { spore, dense colony, and in order } \\
\text { Reverse: Yellowish hyphae, brownish } \\
\text { spore, thick colony, and in order }\end{array}$ & $\begin{array}{l}\text { Eptate hyphae, branchy } \\
\text { miselenium, transparent stem, } \\
\text { and conidium globusa }\end{array}$ \\
\hline 3. & UD 3 & $\begin{array}{l}\text { Upper part: White hyphae, black spore, } \\
\text { dense colony, fibrous, and in order } \\
\text { Reverse: Yellowish hyphae, black } \\
\text { spore, dense colony, and in order }\end{array}$ & $\begin{array}{l}\text { Septate hyphae, branchy } \\
\text { miselinium, transparent stem, } \\
\text { batang, and spore (-) }\end{array}$ \\
\hline 4 & UD 4 & $\begin{array}{l}\text { Upper part: White hyphae, green } \\
\text { spore, thick colony, and in order } \\
\text { Reverse: White hyphae, yellowish } \\
\text { spore, thick colony, and in order }\end{array}$ & $\begin{array}{l}\text { Non-setate hyphae, branchy } \\
\text { miselenium, conidium globusa, } \\
\text { and spore }(+)\end{array}$ \\
\hline 5 & UD 5 & $\begin{array}{l}\text { Upper part: Cottonish white hyphae, } \\
\text { yellowish spore, thick colony, and } \\
\text { in order } \\
\text { Reverse: Yellowish hyphae, yellowish } \\
\text { spore, thick colony, and in order }\end{array}$ & $\begin{array}{l}\text { Non-setate hyphae, non-branchy } \\
\text { miselenium, transparent stem, } \\
\text { and spore }(+)\end{array}$ \\
\hline
\end{tabular}

can also be used to produce ethanol, pollutant, and sorbitol [22].

Table 2: Inulinase activity screening

\begin{tabular}{llll}
\hline No & Types of mold & Area of clear zone & Explanation \\
\hline 1. & UD 1 & $<1-1$ & $(+):$ Low activity \\
2. & UD 2 & $>1-2$ & $(+$ : Low activity \\
3. & UD 3 & $>2-3$ & $(++)$ : Moderate activity \\
4 & UD 4 & $>3-4$ & $(++)$ : Moderate activity \\
5. & UD 5 & $>4$ & $(+++)$ : High activity \\
\hline
\end{tabular}

The results of this study produced the highest inulinase enzyme at UD 5, from five isolates produced through isolation of red dahlia tuber molds labeled UD1, UD2, UD3, UD4, and UD5. The result of identifying molecular showed that the type of $S$. commune was found which indicated that it was a new isolate that would add a new variant of inulinase enzyme that could be used by industry to produce fructose enzymatically from the inulin powder of red dahlia tuber due to the importance of increasing beneficial food production for health by exploring the available local natural resources.

Table 3: Result of inulinase activity measurement

\begin{tabular}{llll}
\hline Isolat Code & Absorbance Sample & Fructose Concentration & Inulinase Enzyme Activity \\
\hline UD3 & 1736 & 157.3333333 & 0.582716049 \\
UD4 & 1532 & 89.33333333 & 0.330864198 \\
UD5 & 1819 & 185 & 0.685185185 \\
\hline
\end{tabular}

DNA amplification product fragments are sequenced in the ITS1 and ITS 4 regions. The nucleotide sequence in fungi can change because the ITS region has a high evolutionary rate. This situation can be used to determine the different species. Fungi with the same sequence of nucleotide bases can be concluded as the same species. Furthermore, the DNA sequencing Bioedit program will provide complete answers to these types of species by producing complete DNA sequences from the endophytic fungi. It is shown in Figure 4. So that the results of the study found S. commune which has a $99 \%$ similarity based on Genbank molecular information.

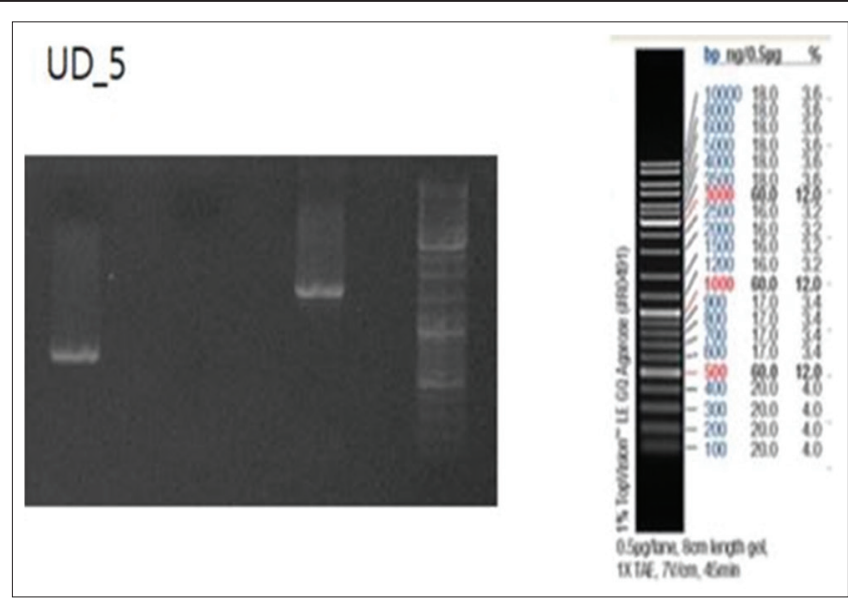

Figure 3: Results of DNA amplification of red dahlia tuber endophytic molds using ITS1/ITS 4 primer pair. M, 100 bp DNA ladder

Table 4: Primer used to amplify rDNA in endophytic mold

\begin{tabular}{ll}
\hline Sequencing Primer & PCR Primer Name Primer Sequences \\
Name Primes Sequences & \\
\hline ITS1 5' (TCC GTA GGT & ITS1 5' (TCC GTA GGT GAA CCT GCG G) 3' \\
GAA CCT GCG G) 3' & \\
ITS4 5' (TCC TCC GCT & ITS4 5' (TCC TCC GCT TAT TGA TAT GC) 3' \\
TAT TGA TAT GC) 3' & \\
\hline
\end{tabular}

A previous study found that endophytic mold from red dahlia tuber which had the highest activity was Aspergillus clavatus, the mold which had superiority in yielding the biggest inulinase enzyme and had better inulinase activity in inulin hydrolysis in the $3^{\text {rd }}$ day within $30 \mathrm{~h}$ of $66.96 \%$ [23]. However, in this research, it was found that there was a new variant, $S$. commune, which had the highest inulinase activity of 0.685185185 . Besides that, the previous research also found that $S$. commune had the potency of good antioxidant which could be the source of good nutraceuticals even though it contained $2.0 \mathrm{mg} / \mathrm{g}$ phenol [24].

Table 5: The identities of endophytic mold

\begin{tabular}{|c|c|c|c|c|c|}
\hline Subject & & & & Score & Identities \\
\hline Accession & Description & Start & t EndCoverage & Bit E-Value & Math/Total Pct. (\%) \\
\hline AB369910.1 & $\begin{array}{l}\text { Schizophyllum } 660 \\
\text { commune }\end{array}$ & 1 & 65298 & 11940.0 & $651 / 653 \quad 99$ \\
\hline
\end{tabular}

In general, the produced inulinase activity was correlated with the amount of reducing sugar produced. The more amount of reducing sugar produced is the higher the inulinase activity and vice versa [25].

Table 6: The strain of endophytic mold

\begin{tabular}{llll}
\hline Kingdom & Family & Genus & Species \\
\hline Eukaryota & Schizophyllaceae & Schizophyllum & Schizophyllum commune \\
\hline
\end{tabular}

The results of this study are different from the previous studies which found sources of inulinase from fungi such as the discovery of Aspergillus fumigatus [26], and Penicillium sp., as well as other sources of inulinase from bacteria such as Pseudomonas sp., Bacillus sp., and Arthrobacter sp, and source inulinase from yeasts such as Saccharomyces sp., Kluyveromyces sp., and Candida sp. [27].

Whereas from the result of this research, it was found that new isolate which produced the 
DNA Squence of UD 5 ITS 1

CTACAGGGACTGCGGAGATCATTAACGAATCAAC AAGTTCATCTTGTTCTGATCCTGTGCACCTTATGTAGTC CCAAAGCCTTCACGGGCGGCGGTTGACTACGTCTACCTCACACCTTAAAGTATGTTAACGAATGTAATCAT GGTCTTGACAGACCCTAAAAAGTTAATACAACTTTCGACAACGGATCTCTTGGCTCTCGCATCGATGAAGAACG

CAGCGAAATGCGATAAGTAATGTGAATTGCAGAATTCAGTGAATCATCGAATCTTTGAACGCACCTTGCGCCCTTTGGTATT CCGAGGGGCATGCCTGTTTGAGTGTCATTAAATACCATCAACCCTCTTTTGACTTCGGTCTCGAGAGTGGCTTGGAAGTG GAGGTCTGCTGGAGCCTAACGGAGCCAGCTCCTCTTAAATGTATTAGCGGATTTCCCTTGCGGGATCGCGTCT CCGATGTGATAATTTCTACGTCGTTGACCATCTCGGGGCTGACCTAGTCAGTTTCAATAGGAGTCGCTTC CAACCGTCTCTTGACCGAGACTAGCGACTTGTGCGCTAACTTTTGACTTGACCTCAAATCAGGTAGGACTACCCGCTGAA CTTAAGCATATCAATAAGGCGGATCGCAAGGAAACGTAAGGGGGAGGGGGCGGGGGGGGGGGGGAGGGGGGGGCGG GGGACGCCCGCCGCGCGCCACCCAACGAACCCAAGAAGTGAAGCGAAGCAGAGGGCCACCCGCGCGAGAAACAACC CACACGCCGGCGACAAAAGAAACCCAGCCCCCAAGCTATTGATCAATATCACGGTGGGGGACGACTTACTCTT CACTAATCCATCTTTTTCGGAGAAGTGTGAAGGATGCAATATCTTATTCCACTGGATGCGACAGTTAACCTTTAAAATACGT CCTAGAATAGGCAATAGGGA TATCCCGCCGTCTAAATCTTTTGTCGTTCGCCGCGGACGGCATCGTAATAAGTTATTATTT CCCGTAATCAGATTAGAAATCTGTCGCTACATTA TATGCTATCACGGGATAGGTACACAGCCTACAC CGAAGATATTTTAATCCGAGTTTGATATATACGTACCGGTAAGTGAATGCATA

DNA Squence of UD 5 ITS 4

GGACCGGGATGTCTACCTGATTTGAGGTCAGTCAAAAGTTAGCGCACAAGTCGCTAGTCTCGGTC

AAGAGACGGTTGGAAGCAGACTCCTATTGAAACTGACTAGGTCAGCCCCGAGATGGTCAACGACGTA

GAAATTATCACATCGGAGACGCGATCCCGCAAGGGAAATCCGCTAATACATTTAAGAGGAGCTGGCTCCG

TTAGGCTCCAGCAGACCTCCACTTCCAAGCCACTCTCGAGACCGAAGTCAAAAGAGGGTTGATGGTATTTAAT

GACACTCAAACAGGCATGCCCCTCGGAATACCAAAGGGCGCAAGGTGCGTTCAAAGATTCGATGATTCACTGAAT

TCTGCAATTCACATTACTTATCGCATTTCGCTGCGTTCTTCATCGATGCGAGAGCCAAGAGATCCGTTGTCGAAAGTTG

TATTAACTTTTTAGGGTCTGTCAAGACCATGATTACATTCGTTAACATACTTTAAGGT

GTGAGGTAGACGTAGTCAACCGCCGCCCGTGAAGGCTTTGGGACTACATAAGGTGCACAG

GATCAGAACAAGATGAACTTGTTTGATTCGTTAATGATCCTTCCGCAGGTTCACCTACGGAAAC

CTTGTTACGATTTTTAACTTCCCAC

Figure 4: Alignments of DNA sequence of UD 5 verificated with pairwise alignment using Bioedit program

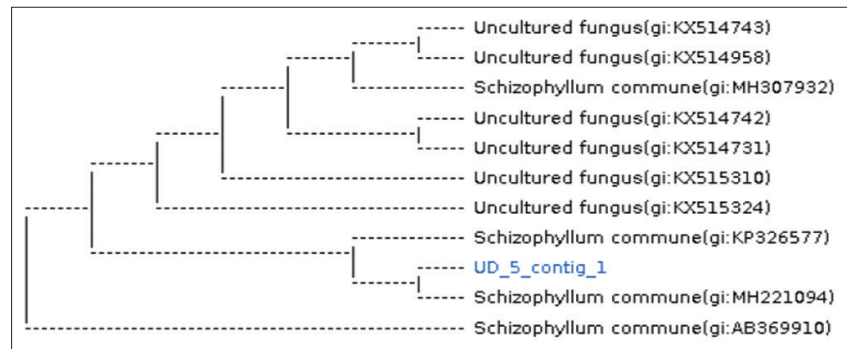

Figure 5: Neighbor-joinin tree (NJ) from the ITS sequence

highest inulinase, S. commune, so that in the future, it is expected the industrial business can use the inulinase enzyme from mold in producing fructose and FOS from the inulin of red dahlia tuber in big scale.

\section{Acknowledgments}

The authors are grateful of this study was funded by the Ministry of Research, Technology, and Higher Education of the Republic of Indonesia, on behalf of Prof. Dr. Chrismis Novalinda Ginting, M.Kes

\section{References}

1. Singh RS, Singh T, Larroche C. Biotechnological applications of inulin-rich feedstocks. Bioresour Technol. 2018;273:641-53. https://doi.org/10.1016/j.biortech.2018.11.031

PMid:30503580

2. Ilgın $M$, Germec $M$, Turha $T$. Inulinase production and mathematical modeling from carobextract by using Aspergillus niger. Biotehnol Prog. 2020;36(1):e2919. https://doi. org/10.1002/btpr.2919 PMid:31581350

3. Surti $\mathrm{A}$, Mhatre $\mathrm{S}$. Optimization of inulinase production by a fungal species isolated from rotten garlic samples. J Appl Biotechnol. 2021;8(2):164-217.

4. Singh RS, Chauhan K, Pandey A, Larroch C. Review biocatalytic strategies for the production of high fructose syrup from inulin. Bioresour Tehnol. 2018;260:395-403. https://doi.org/10.1016/j. biortech.2018.03.127

PMid:29636277

5. Mohan A, Flora B, Girhar M. Inulinase: An Important Microbia Enzyme in Food Industry. Berlin, Heidelberg: Springer Nature Singapore Pvt Ltd.; 2018. p. 237-48.

6. Wan X, Guo H, Liang Y, Zhou C, Liu Z, Li K, et al. The physiological functions and pharmaceutical applications of inulin: A review. Carbohydr Polym. 2020;246:116589.

7. Singh RS, Chauhan K, Kaur K, Pandey A. Statistical optimization of solid-state fermentation for the production of fungal inulinase from apple pomace. Bioresour Technol Rep. 2020;9:100364.

8. Sing RS, SinghT, PandeyA. Fungal endoinulinase production from raw Asparagus inulin for the production of fructooligosaccharides. 
Bioresour Technol Rep. 2020;10:100417.

9. Paul I, Kumar G. Fungal biofactories as potential inulinase sources for production of fructooligosaccharides. Ch. 15. In: New and Future Developments in Microbial Biotechnology and Bioengineering. Amsterdam, Netherlands: Elsevier; 2020. p. $183-210$.

10. Othman Z, Selim A, Bayoumy S, Saber W. Inulinase production from plant materials by some local yeast strains. J Agric Chem Biotechnol. 2020;11:71-7.

11. Taleb KA, Amin SA, Ahmed Al. Production of exo-inulinase from Aspergillus niger and Candida oleophila for degradation of chicory root inulin and ethanol production Middle East J Agric Res. 2019;8(3):855-67.

12. Kusmiyati N, Sunarti S, Wahyuningsih TD, Widodo W. Inulinase activity of extracellular protein of Lactobacillus casei AP in different growth conditions. Key Eng Mater. 2020;840:101-6. https://doi.org/10.4028/www.scientific.net/KEM.840.101

13. Silvera D, Luthfin I, Aulia A, Wahyu PN, Saryono S. Optimization of process parameters for inulinase production from endophytic fungi Fusarium solani LBKURCC67, Humicola fuscoatra LBKURCC68 and Fusarium oxysporum LBKURCC69. Res J Chem Environ. 2018;22(2):70-8.

14. Ali S, Khalid SW. Kinetic and parametric optimization for the enhanced production of a novel fungal exo-inulinase under liquid cultur. Pak J Zool. 2020;52(5):1657-64. https://dx.doi. org/10.17582/journal.pjz/20180225180228

15. Ruswandi, Oktavia B, Azhar M. Determination of fructose levels resulting from inulin hydrolysis with DNS as an oxidizer. J Eksakta. 2018;19(1):14-23.

16. Romadhoni RP, Purbaningtias TE, Muhaimin, Fauzi'ah L. Determination of Reduction Sugar form Banana (Musa acuminata Musa balbisiana Colla) with Different Cooking Process by UV-Visible Spectrophotometer. Proceeding ISCE; 2017. p. 403-9.

17. Hasyyati SN, Suprihadi A, Raharjo B, Dwiatmi K. Isolation and characterization of endophytic fungi from pegagan (Centella asiatica (L.) Urban). J Biol. 2017;6(2):66-74.

18. Suraya N, Piska F, Pratiwi NW, Ardhi A, Saryono A. Molecular Reidentification of Endophytic Fungus LBKURCC40 Isolated from Dahlia's Tuber (Dahlia variabilis) Using the Sequence of ITS rDNA. IOP Conference Series: Materials Science and Engineering; 2019. p. 1-8.

19. Saryono S, Rakhmana S, Rahayu F, Ardhi A, Pratiwi WN, Titania T. Molecular identification of endophytic fungi isolated from the tuber of Dahlia variabilis and exploration of their ability in producing ß galactosidase. Biodiversitas. 2017;18(1):145-52.

20. National Center for Biotechnology Information. BLAST: Basic Local Alignment Search Tool. National Center for Biotechnology Information, US National Library of Medicine; 2021.

21. Singh RS, Singh RP, Inulinases. Current Developments in Biotechnology and Bioengineering. Amsterdam, Netherlands: Punjabi University: Elsevier Science and Technology; 2017. p. 423-46.

22. Risky FU, Wijanarka, Pujiyanto S. Isolation of the yeast producing enzyme inulinase from cherry fruits (Muntingia calabura) and the effect of manganese micronutrients $(\mathrm{Mn})$ on enzyme production. NICHE J Trop Biol. 2019;2(2):27-37.

23. Saryono, Fitriani, Ukun R, Soedjanaatmadja. Several microorganisms that produce inulinase enzymes, isolation and characterization of enzymes from Aspergillus flavus Gmn11.2 local strains. Chim Nat Acta. 2016;4(3):165-74.

24. Debnath S, Saha AK, Panna D. Biological activities of Schizophyllum commune Fr: A wild edible mushroom of Tripura, North East India. J Mycopathol Res. 2017;54(4):469-75.

25. Ma'riffattullah A, Azhar, M, Iryani. Determination of inulinase activity on inulin substrate $\mathrm{A} 1-\mathrm{Kg}$ from mesophilic bacteria rhizosphere Dahlia tuber (Dahlia sp). MENARA IImu. 2019;13(2):153-61.

26. Rawat HK, Soni H, Suryawanshi RK, Choukade R, Prajapati BP, Kango N. Exo-inulinase production from Aspergillus fumigatus NFCCI 2426: Purification, characterization, and immobilization for continuous fructose production. J Food Sci. 2021;86(5):1778-90. https://doi.org/10.1111/1750-3841.15681 PMid:33884619

27. Paul I, Kumar CG. Fungal biofactories as potential inulinase sources for production of fructooligosaccharides. In: New and Future Developments in Microbial Biotechnology and Bioengineering. India: Elsevier Science and Technology; 2020. p. $183-210$. 